\title{
THE NEW BIRD IDENTIFICATION BOOKS
}

J. B. GOLLOP, Canadian Wildlife Service, 115 Perimeter Road, Saskatoon, Saskatchewan. S7N 0X4

If all species of birds shared one characteristic of the Blue Jay - a similar plumage for adult and young, male and females, spring, summer, fall and winter - one revised and 2 new identification guides would not have appeared just in time for Christmas, 1983. But they do not and they did and this article attempts a review of 2,452 pages of 6 volumes under 4 titles. At the outset, however, readers should keep in mind that a reviewer's opinions are but one person's point of view. Note a discrepancy in the following from 2 reviews of Peterson's 1980 guide: one reads: "The Catharus thrushes are too plump and shown in a posture that suggests that they walk like an Ovenbird rather than hop as thrushes typically do." 5 The other proclaims: "These portraits range from superb (the 'brown thrushes' on page 223) ..."6

The 4 titles reviewed in paperback editions are:

PETERSON, R.T. 1980. A field guide to the birds of eastern and central North America. Houghton Mifflin, Boston. 4th edition. Pages: 384 in 1 vol. Size: $180 \times 112 \times 18 \mathrm{~mm}(7.1 \times 4.4 \times 0.7$ in.). Weight: $435 \mathrm{~g}(1.0 \mathrm{lb})$ Writers: 1. Artists: 1 (same as writer). Pages of bird plates: 136. Number of species: 583 illustrated of which 131 are on 8 plates of stragglers. Maps: 390,6 per page at end, $56 \times 50 \mathrm{~mm}(2.2 \times 2.0 \mathrm{in}$.), mainly eastern North America and regional maps. Introduction: 22 pages, including books on songs, nests and good birding areas, Peterson identification system, area of guide, about maps, ranges, drawings vs. photographs, subspecies, acknowledge- ments, map, life list, how to identify birds ( 7 pages), parts of a bird ( 34 labels), definitions. Sequence of species: from aquatic to less aquatic to land birds, the latter partly in American Ornithologists' Union (AOU) order and partly in groups of similar species. ${ }^{8}$ Species treatment: usually 4 paragraphs, 5 headings, facing illustration; length, sometimes wingspread, more often a single value (rather than a range) in inches and $\mathrm{cm}$; description, similar species, voice, worldwide range, reference to map (or range if no map), habitat. Uses old and new official and his own bird names. ${ }^{8}$ Special features: arrows on plates pointing to diagnostic field marks. Price: $\$ 13.95$ paperback, \$19.95 hardcover.

ROBBINS, C.S., BERTEL BRUUN and H.S. ZIM. 1983. A guide to field identification. Birds of North America. Golden Press, New York. Revised edition. Pages: 360 in 1 vol. Size: $190 \mathrm{x}$ $118 \times 17 \mathrm{~mm}(7.5 \times 4.6 \times 0.7 \mathrm{in}$.$) .$ Weight: $375 \mathrm{~g}$ (0.8 lb.). Writers: 3 . Artists: 1. Pages of bird plates: 172. Number of species: $810 \pm$ illustrated (from introduction). Maps: $602 \pm$ with species, $25 \times 25 \mathrm{~mm}(1 \times 1$ in.), North America and regional. Introduction: 12 pages, including definitions, how to use book, bird songs, sources of recordings, describing birds, birdwatching, parts of a bird (44 labels). At the end of the guide is a list of 33 important bird books. Sequence of species: families are generally in AOU order but similar species are grouped within families. Species treatment: one paragraph, no headings, facing illustration; length, occasionally wingspread, a single value in inches only; abund- 
ance, food and behaviour (sometimes), breeding habitat, description, comparison, song. Four old names are retained (Louisiana and Green herons, Barn Owl, Common Flicker); other old names are given in index only. Special features: $320 \pm$ sonagrams (prints of bird songs showing length and frequency range), monthly spring migration lines and migration route on map, length of bird in live position (not stretched out as in other books), index with boxes for life list. Price: $\$ 9.95$ paperback, \$12.95 hardcover.

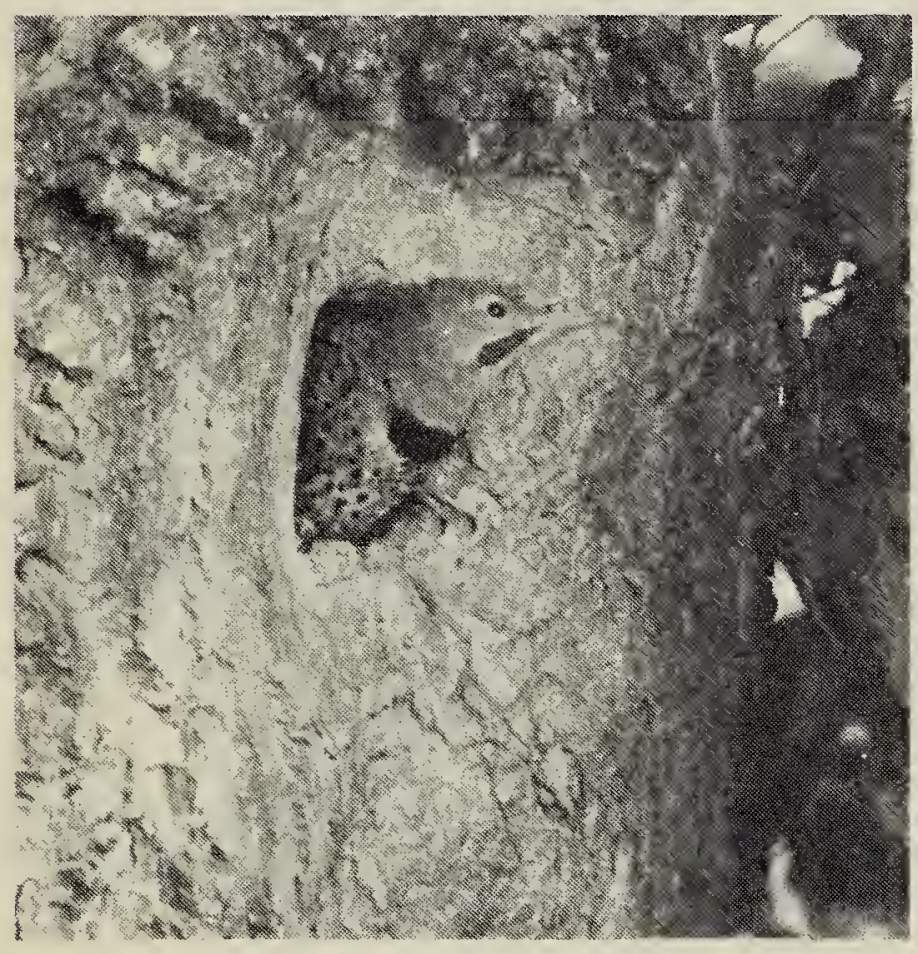

Northern Flicker James Hamilton

SCOTT, S.L. (editor). 1983. Field guide to the birds of North America. National Geographic Society, Washington, D.C. Pages: 464 in 1 vol. Size: $204 \times 127 \times 22 \mathrm{~mm}(8.0 \times 5.0 \times 0.9$ in. $)$. Weight: $650 \mathrm{~g}(1.4 \mathrm{lb}$.). Writers: 8 . Artists: 13. Pages of bird plates: 220. Number of species: 806 illustrated (advertising implies "nearly 800"). Maps: 640 with species, $23 \times 26 \mathrm{~mm}$ $(0.9 \times 1.0$ in.), North America and regional. Introduction: 12 pages, including bird names, plumages, parts of a bird (42 labels), behaviour, definitions, birding, binoculars, telescopes, checklists. Sequence of species: from aquatic to less aquatic to land birds, the last in AOU order for families but similar species grouped together within families. Species treatment: one paragraph, no headings, facing illustration; length, sometimes wingspread, usually one value in inches and $\mathrm{cm}$; description, comparison, food and winter range (sometimes), habitat, songs and calls, previous name (if applicable). Special Features: 2400 different plumages, index with boxes for life list. Price: $\$ 19.95$ paperback.

FARRAND, JOHN, JR. (editor). 1983. The Audubon Society master guide to birding. Knopf, New York. Pages: 447 in Vol. 1, loons to sandpipers; 398 in Vol. 2, gulls to dippers; 399 in Vol. 3, Old World warblers (kinglets) to sparrows. Size: $204 \times 126$ $\times 61 \mathrm{~mm}(8.0 \times 5.0 \times 2.4$ in. $)$. Weight:

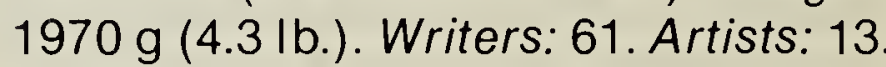
Photographers: 208. Pages of bird plates: 510 (1245 photos, 193 paintings), plus 422 marginal drawings. Number of species: 719 illustrated plus 116 dealt with by text only at 6 or 7 species per page. Maps: 650 with species, $33 \times 27 \mathrm{~mm}(1.3 \times 1.1$ in.), North America and regional. Introduction: 24 pages, identical in each volume and including acknowledgements, about the Audubon Society, preface, introduction, parts of a bird (40 labels), how to use book, map, how to identify and find birds, a review of orders in the particular volume. After the main species treatments there are 21 to 31 pages of material made up of 5 to 7 pages of accidentals, glossary (4 to 6 pages), brief author and artist biographies and credits. These sections appear in each volume. In addition, Vol. 1 has 3 pages on classification and nomenclature; Vol. 2 has 9 pages on birding equipment, reporting a rarity and a list of rare bird alerts; $V$ ol. 3 has 3 pages entitled "Beyond Bird Identification" (in introduction). Sequence of species: new AOU order, species by species. Species treatment: usually 5 paragraphs with headings, facing plate. The introductory paragraph 
(abundance, habitat, nesting, behaviour, etc.) is followed by description (length in inches and $\mathrm{cm}$, usually a range), voice, similar species, range (breeding and winter, occasionally migration). Special features: key plumage arrows on miniature, marginal, black and white reproductions of color illustrations. Price: $\$ 18.50$ per volume paperback (can be purchased separately).

In the remainder of this review which is concerned primarily with Prairie Province birds, the 4 guides will be referred to as Peterson, Robbins, NGS (National Geographic Society) and AMGB (Audubon Master Guide to Birding).

\section{Plates}

Peterson A review of this guide appeared in the March 1981 Blue Jay ${ }^{7}$ More extensive reviews have appeared in Birding and Continental Bird Life. ${ }^{2}, 11$ These reviews have also pointed out some errors, e.g., Ferruginous Hawks have feathered legs; the 3rd winter Herring Gull much more closely resembles a 2nd winter bird (Harrison) ${ }^{9}$; the solid black band on the tail of the 2nd winter Laughing Gull should be broken (Harrison) or spotted (NGS) or non-existent (Robbins)! (This plumage is not mentioned in AMGB.) Peterson probably does the best job of putting similar species together.

Robbins The revised volume requires a review within a review. The new edition presents a more attractive appearance than its predecessor. The type face is new, the maps are more brightly coloured and more use is made of regional maps to better illustrate ranges. A check of the first 50 pages of songbirds shows that there are 11 new sonagrams and that many of the old ones are larger and more clearly printed. However, there are still no sonagrams to help separate Willow from Alder Flycatcher. The 1983 version is 20 pages longer than the 1st edition.

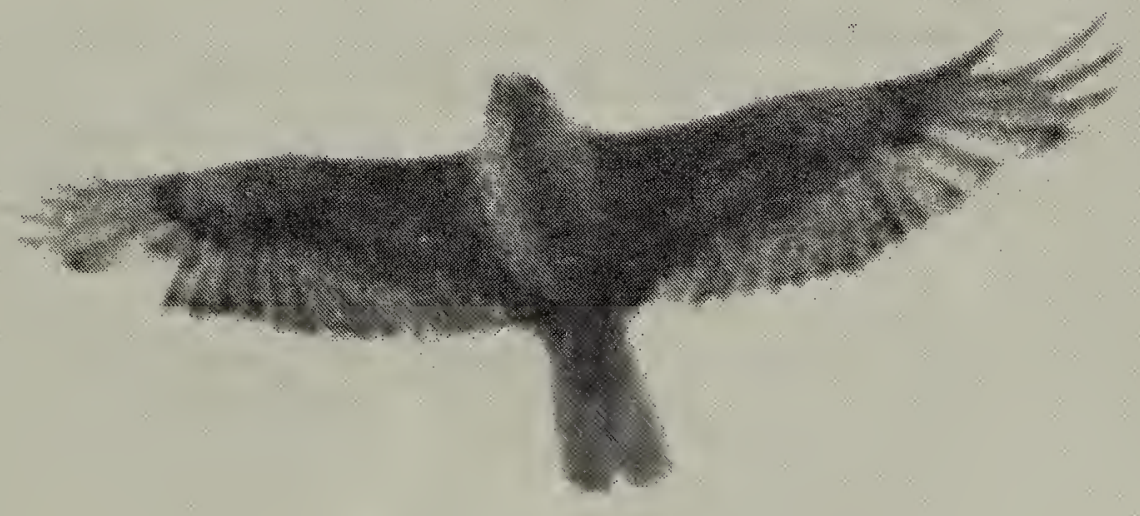


A quick comparison shows the new volume to have 130 plates with the same species composition as the 1966 version, 21 plates with one (rarely 2) new species inserted and 20 largely or completely new plates. The additional species are, for the most part, stragglers. Such additions usually reduce the amount of text per species, but the new edition has far fewer wing tips, tails and feet cut off in the plates. However, accuracy and consistency in colour reproduction have been and still are a problem with this publisher. The new edition is much better and many plates are warmer and grayer (as opposed to brown) but this is not consistent from copy to copy. In the books I compared, the plates on pages $43,125,136,137,339$, for instance, of the 1983 version are noticeably more gray-blue, page 215 is grayer and yellower, 321 is yellower, etc., etc.

Robbins' o Northern Harriers are apparently immatures; females are correctly shown in Peterson and NGS but not illustrated in AMGB.

National Geographic The main problem with this book is that not all the good artists are equally good. The Canada geese and goldfinches look like porcelain pieces. There is no dark-phase Ferruginous Hawk. I did not at first identify the Black-andwhite Warbler because the bird on the right caught my attention. I found that Harris' and White-crowned sparrows are not quite the shapes of those in my backyard. The flying swallows look awkward to me and the $\sigma^{\prime \prime}$ Brewer's Blackbird head is too blue. A better job could have been done in grouping similar species. It is difficult to understand why sparrows with streaked underparts were separated into 2 groups by those with unstreaked breasts and juncos.

This would have been close to an ideal field guide if arrows had been used to point out diagnostic features. These could still be added from Peterson and AMGB and it would be a valuable learning experienc.e.

NGS illustrates more field-identifiable subspecies than any other guide. Two or more subspecies are shown for $83 \pm$ species ( 6 for Fox Sparrow, 5 each for Canada Goose, Horned Lark, Song Sparrow and Rosy Finch), 2 or more colour phases for each of $41 \pm$ species and 7 hybrids (none for Indigo and Lazuli buntings).

The clarity of detail in these pictures and presentations of so many plumages not only offers more insight into bird variation but also challenges the birdwatcher to look more closely at each bird in the field to determine age, sex, race or colour phase.

Audubon Master Guide According to the preface, "For years the birding community has been waiting for an advanced guide ... For this reason we have tried to prepare the most complete, up-to-date, and useful field identification guide ever devised." As I see it, the format precludes usefulness and the decision in favour of photographs almost assured it would be neither complete nor most useful.

Rigid adherence to the AOU order would seem to largely defeat the purpose of a field guide. It apparently assumes that the observer recognizes every bird seen and needs the guide only for confirmation. How close together are similar species? Five peeps require 12 pages (same page in all other guides); our eagles are 30 pages apart (same page in all other guides); warblers with wingbars begin and end 70 pages apart (16 in NGS); nutcracker and shrike are in different volumes.

The other problem is photographs. The authors and editors of photographic bird guides may plead and proclaim all they wish about the super- 
iority of photos over paintings but they have yet to demonstrate it. ${ }^{3}{ }^{17}$ Many songbirds in the field are best identified from a side view with a significant portion of the front and underparts visible. However, too many of the passerines in this compendium were photographed from above the horizontal and/or behind, too often not showing shape and extent of throat, breast and belly markings, even though arrows claim these key points are illustrated in some cases, e.g., streaked breast of Sprague's Pipit, "narrow gray breastband" of immature Magnolia Warbler, black throat and upper breast of $\sigma^{2}$ House Sparrow.

Other problems with photos include: (1) species presented from angles that are of little use in identification, e.g., Varied Thrush, ơ Tennessee Warbler, ơ Orchard Oriole; (2) similar species not photographed from the same angle in the same light, e.g., $\sigma^{\prime}$ Connecticut and Mourning warblers. o Greenwinged and Blue-winged teals; contrasting colours of Gray-cheeked and Swainson's thrushes are misleading (in fact, none of the thrush photos depict breast markings as well as the other guides); (3) photos too light and too dark, e.g., Great Blue Heron (too light), Sedge and Marsh wrens on the same page, \& Yellow-headed Black- bird (too dark); (4) discrepancy between text and photo, e.g., "checkered black, gray and white upperparts" of breeding adult Greater Yellowlegs vs. brown as illustrated, "yellowish legs" of dark-legged adult Pectoral Sandpiper; (5) conflicts between photos of the same species, e.g., Dusky and Western flycatchers, Sedge Wren, Ovenbird; (6) contrast between photo and painting, e.g., Common Snipe, Marbled Godwit (paintings better); (7) shadows hiding details, e.g., Gray Partridge, adult Lewis' Woodpecker; (8) bills and tails lost in backgrounds, e.g., Trumpeter Swan, Baird's Sandpiper; (9) the juvenile European Starling is too richly coloured and why was an atypical $\&$ Wilson's Warbler (with a black cap) shown?

While some photos are redundant, e.g., American Dipper, Brown Thrasher, Vesper Sparrow, there are not enough in other cases, e.g., no dark Snowy Owl, no immature Burrowing Owl or Mountain and Eastern bluebirds.

The artists in AMGB are not as good as those in the other guides (e.g., Field Sparrow photo vs. painting). It is also surprising that a painting had to be used for immature Whooping Crane.

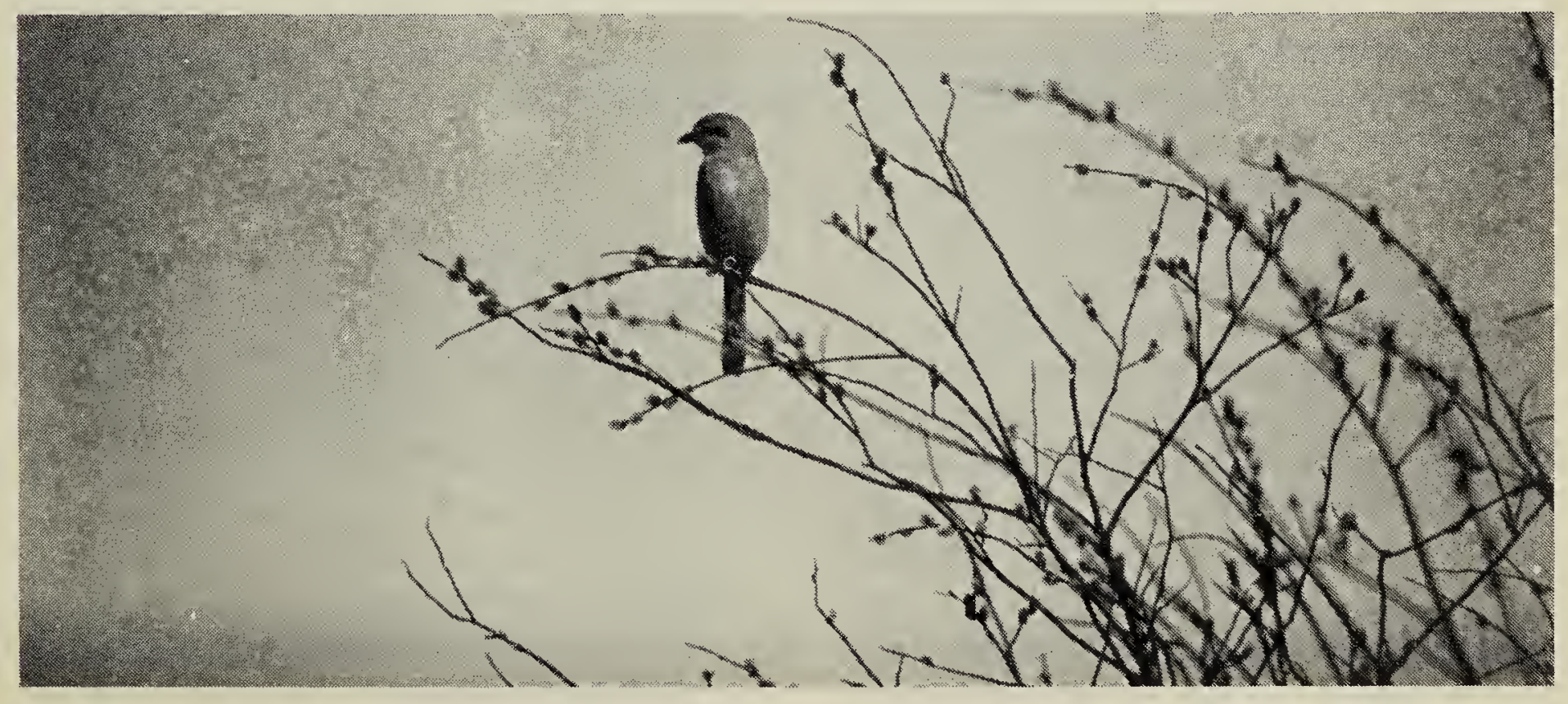


Some photos in the earlier Audubons are better than in the current one, e.g., adult Pectoral Sandpiper, $\sigma^{\circ}$ and $q$ Mourning Warblers ${ }^{3}$ (quite different colours in the 2 books), and Northern Rough-winged Swallow, Savannah Sparrow. ${ }^{17}$

Illustrations of birds in flight are, for the most part, marginal drawings. There are no illustrations for ducks flying overhead.

Scale is also lost when each bird fills a frame and is often the only species on a page. When 2 species are on the same page, the scale is sometimes misleading, e.g., Barred Owl is shown as smaller than Burrowing Owl, Northern Flicker is smaller than Black-backed Woodpecker on one page but on the next it is larger than Pileated; Pine Grosbeak is the same size as Purple Finch.

In summary, I do not think this is a very good guide for beginners or "masters" because similar species are not grouped for ready comparison, because too few plumages are illustrated, too many of these are poorly shown and because the text is no better than that in NGS.

\section{Maps}

All 4 titles map the ranges of most species. Peterson's maps are about 8 times the scale of the smallpostage-stamp maps of the other authors and his ranges are not restricted to eastern North America. For eastern species nesting primarily in the Arctic, breeding ranges are also shown. All guides except AMGB use 4 colours for base maps and ranges. The Audubon guide uses one colour for both base map and distribution with diagonal lines to designate ranges. These fail to do the job for narrow coastal occurrences. This inadequacy is also true of the yellow used by NGS in designating small ranges, e.g., Hudsonian Godwit.
Maps in both Peterson and the NGS guide show provinces and states. The other two do not and are therefore much less useful, although AMGB does devote up to 18 lines of text (usually fewer than 10) to provincialstate distribution. Robbins' maps are the only ones to consistently give information on migration.

A surprising disappointment for a map-oriented society is NGS' depiction of the Canadian Arctic. Victoria and Banks islands are one, as are Melville and Prince Patrick. Somerset and Prince of Wales islands have apparently become part of Boothia Peninsula. These and other deficiencies, e.g., Vancouver Island, are handled adequately in the other guides. Tsk! Tsk!

Probably no 2 guides' maps agree on breeding and wintering ranges. One has only to compare such conspicuous and well-known species as Canada Goose and Mallard to see differences in province and state distributions. However, not one of the 4 titles includes Canada (except for B.C.) in the wintering range of the Merlin. And this in spite of Merlin's appearing in Christmas Bird Counts (CBC) from each of the Prairie Provinces and published in American Birds annually since the mid-1970s. In 1976, 26 Merlins were reported on December counts in Alberta, 5 in Saskatchewan and 3 in Manitoba. ${ }^{10}$ Edmonton's count of 14 that year was tops among all CBC's in North America. ${ }^{15}$

A partial check showed that some AMGB ranges are better for Canada than NGS', e.g., breeding Northern Mockingbird and winter Blue Jay, Cedar Waxwing and Willow Ptarmigan.

\section{Table of Comparisons}

Table 1 makes additional comparisons based primarily on 6 groups of Prairie Province birds. The species 
Table 1. PICTURE AND TEXT COMPARISONS

$\begin{array}{lcccc}\text { Guide } & \begin{array}{c}\text { Peterson } \\ \text { (Revised) }\end{array} & \begin{array}{c}\text { Robbins } \\ \text { (Revised) }\end{array} & \begin{array}{c}\text { National } \\ \text { Geographic }\end{array} & \begin{array}{c}\text { Master } \\ \text { Guide }\end{array} \\ \text { Coverage } & \text { E. N. Am. } & \text { N. Am. } & \text { N. Am. } & \text { N. Am. } \\ \text { Species Group } & & & & \\ \text { Ducks } & 31 / 245 & 31 / 223 & 32 / 169 & 32 / 135 \\ \text { Vultures-Falcons } & 20 / 90 & 21 / 102 & 21 / 109 & 21 / 85 \\ \text { Shorebirds } & 42 / 176 & 47 / 174 & 47 / 195 & 47 / 168 \\ \text { Gulls } & 19 / 83 & 19 / 82 & 19 / 116 & 19 / 82 \\ \text { Warblers } & 34 / 101 & 36 / 163 & 36 / 106 & 36 / 89 \\ \text { Sparrows } & 20 / 42 & 22 / 70 & 22 / 79 & 22 / 55 \\ \text { Total } & 166 / 737 & 176 / 814 & 177 / 774 & 177 / 614 \\ \text { Average } & 4.4 & 4.6 & 4.4 & 3.5\end{array}$

Usual No. of Species per plate (all species in group)/Words per species:

\section{Ducks}

Vultures-Falcons

Shorebirds

Gulls

Sparrows
Warblers

$\begin{array}{cc}3-5 / 89 & 3-5 / 58 \\ 3 / 109 & 3-5 / 74 \\ 3-5 / 101 & 5-7 / 55 \\ 3-7 / 99 & 4-6 / 75 \\ 4-5 / 81 & 4-5 / 67 \\ 3-5 / 87 & 4-6 / 72\end{array}$

Pages per group (text and plates):

Ducks

Vultures-Falcons

Shorebirds

Gulls

Warblers

Sparrows
26

22

28

10

22

12

\section{0 \\ 18 \\ 28 \\ 12 \\ 28 \\ 18}

$4 / 92$
$2-4 / 132$
$4-5 / 83$
$2-4 / 140$
$3-5 / 92$
$3-4 / 115$

$1-2 / 324$

$1-2 / 423$

$1-2 / 308$

$1 / 418$

$1-2 / 325$

$1-2 / 337$ included in each group were tabulated from 5 sources. ${ }^{4} 12 \quad 13 \quad 14 \quad 16$ The 1st section gives the number of Prairie Province species covered and the number of illustrations of them. Every illustration considered helpful in identification was counted, from whole bird to diagnostic feather to some birds in background flocks. The 2nd section gives the number of species most often depicted on a plate where species are given major treatment. The words-perspecies were calculated by counting lines for the same 10 species in each group, selected systematically (every 2nd or 3rd species in NGS depending on group size), and by counting words in 10 lines that included each of the same 10 species scattered through the guides, i.e., 100 lines were counted.

Section one indicates that Peterson does not include and/or illustrate some Prairie Province species, mainly associated with Cypress Hills and mountains and some stragglers. It also shows that of the 3 other guides, AMGB has the fewest illustrations. NGS has the most for 4 of the 6 groups. Peterson's and Robbins' high number of duck illustrations are largely the result of using 4 paintings to show 
upper and lower surfaces of males and females in flight, a feat ingeniously accomplished in NGS with just 2 paintings per species - male and female. Robbins' superiority in number of warbler illustrations comes mainly from 2 special pages devoted to warbler heads.

Section 2 indicates another deficiency of AMGB - usually only one species per page or, more often, one picture of one species and 2 of another on the same page, whereas the other guides frequently permit comparison of 3 to 5 species per plate. The 3rd section of the table shows another implication of this arrangement. Note the number of pages that must be searched to find one or more species in a group -2 to 3 times as many in AMGB.

A related point is that the first 3 guides have written descriptions opposite the entire species. AMGB often does not accomplish this because the adult male in breeding plumage is frequently the 3rd photo for a species and is often on the 2 nd page of the species treatment. But the breeding male is the 1st plumage described - on the previous page!

\section{Text}

In an attempt to evaluate the text, I selected 10 pairs of species to determine how well the words separated the members of each pair for me. Such a comparison is so subjective that no other birdwatcher is likely to reach the same ratings I did. The pairs were $q$ Blue-winged and Green-winged teals, $q$ Common and Barrow's goldeneyes, immature California and Herring gulls, Cooper's and Sharp-shinned hawks, Greater and Lesser yellowlegs, Semipalmated and Western sandpipers, Least and Alder flycatchers, Loggerhead and Northern shrikes, fall Blackpoll and Bay-breasted warblers, Claycolored and Brewer's sparrows. For each pair the 4 texts were read and notes made. Then the notes were rated from best ( 4 points) to poorest (1 point); there were some ties. The totals indicated that NGS was best (35 of a possible 40 points), AMGB next (30 points) with Peterson and Robbins tying with 20 points each (mainly because Peterson does not include Brewer's Sparrow).

With 61 specialists usually permitted a page per Prairie Province species, one would have expected AMGB text to excel over all competition. I don't think it does, as illustrated above and, as another reviewer has written, "in some instances you may search long and hard for those 'master' identification tips that have not been published elsewhere."1

In comparing the above species, 3 other problems appeared in AMGB. (1) Under Common Goldeneye, the $q$ Barrow's is described as having a "darker breastband"; under Barrow's Goldeneye, the $\&$ Barrow's is said to have a "white chest, breast, and belly." (2) In both Sharpshinned and Cooper's hawks, the "tail is crossed by 4 dark straight bands." The former is drawn this way but the latter has only 3 dark bands. (The number of bands may actually vary.) (3) The descriptions of both Clay-colored and Brewer's sparrows include the terms "cheek patch" and "whisker mark." Neither is labelled in "Parts of a Bird" on p. 15. The same is true for "mantle" used in gull descriptions. However, readers need only turn to p. 10 of NGS to locate them.

Additional evidence of the thoroughness of the NGS guide and the deficiencies of the others may be seen in the number of non-breeding sparrow plumages illustrated. Of the 20 sparrows on the Saskatchewan list, NGS illustrates 16 juveniles, Robbins 7, AMGB 6 and Peterson 4. Immature 
plumages are given for $5,7,6$ and 4 , respectively, and winter for $5,1,0$ and 2.

The 4 books were taken to Universal Bindery, Saskatoon, for an appraisal of the binding. All are Smyth-sewn, the same technique used for hardcover books, and all were considered to be equally sturdily bound.

I think it is safe to say that for the Prairie Provinces Peterson and Robbins have now been eclipsed. I also feel that the Audubon Society has given its name to the 3 most disappointing bird identification guides of the last decade. ${ }^{3},{ }^{17}$ If I were buying only one field guide for myself (or for someone else) or taking only one with me on vacation, it would be Shirley Scott's National Geographic. All four of these guides are available from Blue Jay Bookshop.

\section{Acknowledgements}

My thanks to M.D. Gilliland for checking data, commenting on the manuscript and typing early drafts. Thanks also to A.R. Smith and P.S. Taylor, who commented on maps, artists and manuscript. I also much apprecaite the cooperation of Chris Escott, Wayne Harris and Bob Luterbach for contributing their capsule reviews below.

'ARBIB, ROBERT. 1983. The Audubon Society master guide to birding. (A review) Am. Birds 37:921-922.

${ }^{2}$ ARMISTEAD, HENRY. 1981. Bird Book wars. The emperor strikes back. Birding 13:117-128 (Includes comments by Peterson)

${ }^{3}$ BULL, JOHN and JOHN FARRAND, Jr. 1977. The Audubon Society field guide to North American birds. Eastern region. Knopf, New York.

${ }^{4}$ CLEVELAND, N.J., C.W. CUTHBERT,
G.D. GRIEEF, G.E. HOLLAND, P.A. HORCH, R.W. KNAPTON, R.F. KOES, N.F. MURDOCH, W.P. NEILY, I.A. WARD. 1980. Birder's guide to southeastern Manitoba. Eco Series 1, Man. Naturalists Society, Winnipeg, Man.

${ }^{5}$ DUNN, JON. 1981. A field guide to the birds. (A review) Auk 98:641-644.

${ }^{6}$ GAWN, STEPHEN. 1982. A field guide to the birds east of the Rockies. (A review) Can. Field-Naturalist 96:109110.

${ }^{7}$ GOLLOP, J.B. 1981. A field guide to the birds east of the Rockies. (A review) Blue Jay 39:59-62.

${ }^{8}$ GOLLOP, BERNARD. 1983. Birds - New names, new order. Blue Jay 41:186188.

'HARRISON, PETER. 1983. Seabirds. An identification guide. Houghton Mifflin, Boston.

${ }^{10}$ HEILBRUN, L.H. 1977. The seventyseventh Audubon Christmas Bird Count Am. Birds 31:453-457.

${ }^{11}$ KAUFMAN, KENN. 1981. Abridged too far ...? Continental Bird Life 2(1):22-27.

${ }^{12}$ KREBA, ROBERT. 1983. Field checklist of Saskatchewan birds. Mus. Natural History, Regina, Sask.

${ }^{13}$ LANE, J.A., and BONNIE CHARTIER. 1983. A birder's guide to Churchill. L\&P Press, Denver Colo.

${ }^{14}$ MANITOBA MUSEUM OF MAN AND NATURE, 1979. Manitoba birds field checklist. Man. Mus. Man and Nature, Winnipeg, Man.

${ }^{15}$ MONROE, B.L., Jr. 1977. Summary of highest counts of individuals for Canada and the U.S./Am. Birds 31:910916.

${ }^{16} \mathrm{PROVINCIAL} \mathrm{MUSEUM} \mathrm{OF} \mathrm{ALBERTA.}$ 1981. Check-list of Albertan birds. Prov. Mus. Alberta, Edmonton, Alta.

17UDVARDY, M.D.F. 1977. The Audubon Society field guide to North American birds. Western Region. Knopf, New York. 